Editorial

\section{Pedro Clóvis Junqueira}

Milton Artur Ruiz

The old warrior died. On hearing the news and starting to write about one of the key mentors of the Brazilian Society of Hematology (SBHH), I felt ashamed about not knowing more about one of the main activists in the fight for the recognition of hemotherapy as a medical specialty in Brazil.

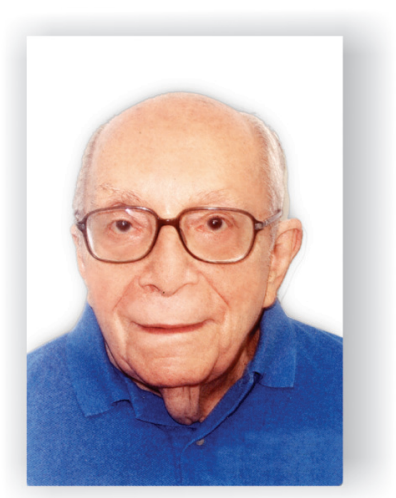

I remember the first time I saw him as if it were yesterday. In Curitiba in 1974 in the National Hematology Congress organized by the Brazilian College of Hematology, a figure hardly caught my attention. However someone whispered in my ear, "Look, there is the enemy." I only understood this observation some time later, after all, I was young and inexperienced, just a resident, distant and neophyte to the political problems involving the specialty. Time passed and the SBHH was restructured, acquired a head office in Avenida Rio Branco in Rio de Janeiro under his presidency and the master began to attract young people to the society. Already participating as a listener in conversations between the older members, I noted that Master Junqueira was at all times the center; stories and recollections of the $\mathrm{SBHH}$ were told and romanticized. He told all with decorum, about the foundation of SBHH in the wake of the success of the first Paulista Congress in 1949. He praised, or criticized, the facts in his Maranhense-Carioca way and almost always ended his stories with loud laughter. He described the confusion that occurred during the organization of the first Brazilian Congress in the Quitandinha Hotel in Petropolis, Rio de Janeiro, and also his attempts to become the first director of the SBHH. He described the odysseys to organize the first congresses and cleverly told the story of how the symbol of society emerged and the reason for the existence of the fibrinogen molecule in the center of the blood drop in the logo of the SBHH. In fact, he said, this was a reference to a type of bush that was very common in the city of Juiz de Fora, Minas Gerais, the location of the congress in 1953. In an amateurish and playful way he explained that at the start of every session a branch of the said bush was given to the speaker as a symbol of the event and so it passed from hand to hand during the Congress.
Thus the symbol of SBHH was formed - from a joke and sketches at restaurant tables.

During his tenure as president, $\mathrm{SBHH}$ became a recognized entity, as well as the voice of Hematology and Hemotherapy in the Brazilian Medical Association and in that very year the first examination for specialist in Hematology was held. This was the second time I saw him, happy and excited, in the Hospital dos Servidores do Estado in São Paulo, the place of the examination.

The years went by and congresses came and went, such as the one in Brasilia, when the $\mathrm{SBHH}$, influenced greatly by him I believe, elected the first woman president. In those days, the general meetings were among the most awaited moments of congresses, where everything was discussed and politics was all about despite the difficult years; in all of them, master Junqueira pontificated.

I got to know him more closely in 1981 during the Brazilian Congress in Fortaleza. Influenced by Celso Guerra I agreed to participate on the board of the SBHH as secretary general. Since then our contact was frequent, and his stimulation of the Bulletin, which had existed since 1973, was incessant. He always explained that the members needed to be informed and that, for many, the Bulletin was the only vehicle through which they received information about their specialty. He participated in the modification and evolution of the Bulletin, and I believe, that the oldest members amongst us still remember his section "Future Point". This paraphrased a former coach of Flamengo Football Club (another of his passions) who used advanced terminology for the moves in soccer, i.e., the Master always looked to the future of the specialty.

Enthusiastic about advances, he was delighted with novelties. Who has never heard him describe the "leapfrog" blood donation program, as well as declaring that bone marrow transplant was going to be a huge success and this at the start of the 1990s. He visited everyone, participated in events, literary evenings, academies, that is, he was there in all the events of the SBHH. He wrote and kept information on everything that happened and, especially, edited and encouraged everyone to participate in books on Hematology. Thus, because of him, he made me address the memories of the SBHH that, for some time, became part of the most successful subjects in the Bulletin.

Even after the transformation of the Bulletin to a journal, "Boletim da Sociedade Brasileira de Hematologia e Hemoterapia" (Bol Soc Bras Hematol Hemoter., ISSN 0102 7662) and later into the current "Revista Brasileira de Hematologia e Hemoterapia" (RBHH) he sent me, in his small round handwriting, information on the lives of former colleagues and stories from when hemotherapy used glass flasks, and collaborated with several articles. In the 50-year celebrations of the SBHH, along with his colleagues in Rio de Janeiro, he organized an unforgettable congress - his joy overflowed; it was not complete only because of the loss of his great friend, Professor Halley Pacheco de Oliveira, during the event.

I could go on describing his educational activities, participation in congresses in Brazil and abroad, titles and 
honors received from $\mathrm{SBHH}$ and other institutions. ${ }^{(1)} \mathrm{I}$ apologize to Norma and to all his colleagues who had the opportunity and privilege to be more often in his company, because I feel like a usurper, restricted to recalling his ever pleasant and happy words to me, his support, always when I needed as director of the SBHH and his unrestrained encouragement as editor of the RBHH.

\section{Reference}

1. Pimentel MA. Trajetoria de um Mestre. Biografia do Prof. Pedro Clóvis Junqueira. Juiz de Fora: Editar; 2000. 145p.

Submitted: 10/19/2010

Accepted: 10/21/2010

Hematology and Hemotherapy Service, Medicine Department, Faculdade de Medicina, Universidade de São Paulo - USP,

São Paulo (SP), Brazil

Correspondence: Milton Artur Ruiz

Rua Catarina Nucci Parise, 760 - Jardim Vivendas

15090-470 - São José do Rio Preto (SP), Brazil

E-mail:milruiz@yahoo.com.br 